Published in final edited form as:

Curr Mol Pharmacol. 2011 June 1; 4(2): 106-114.

\title{
In Vivo Space Radiation-Induced Non-Targeted Responses: Late Effects On Molecular Signaling In Mitochondria
}

\author{
Mohit R. Jain ${ }^{1}$, Min $\mathrm{Li}^{2}$, Wei Chen ${ }^{1}$, Tong Liu' ${ }^{1}$, Sonia M. de Toledo², Badri N. Pandey², \\ Hong Li ${ }^{1}$, Bernard M. Rabin ${ }^{3}$, and Edouard I. Azzam ${ }^{*}$, \\ ${ }^{1}$ Department of Biochemistry and Molecular Biology, University of Medicine and Dentistry of New \\ Jersey, New Jersey Medical School Cancer Center, Newark, New Jersey, USA \\ ${ }^{2}$ Department of Radiology, University of Medicine and Dentistry of New Jersey, New Jersey \\ Medical School Cancer Center, Newark, New Jersey, USA \\ ${ }^{3}$ Department of Psychology, University of Maryland Baltimore County, Baltimore, MD, USA
}

\begin{abstract}
The lack of clear knowledge about space radiation-induced biological effects has been singled out as the most important factor limiting the prediction of radiation risk associated with human space exploration. The expression of space radiation-induced non-targeted effects is thought to impact our understanding of the health risks associated with exposure to low fluences of particulate radiation encountered by astronauts during prolonged space travel. Following a brief review of radiation-induced bystander effects and the growing literature for the involvement of oxidative metabolism in their expression, we show novel data on the induction of in vivo non-targeted effects following exposure to $1100 \mathrm{MeV} /$ nucleon titanium ions. Analyses of proteins by twodimensional gel electrophoresis in non-targeted liver of cranially-irradiated Sprague Dawley rats revealed that the levels of key proteins involved in mitochondrial fatty acid metabolism are decreased. In contrast, those of proteins involved in various cellular defense mechanisms, including antioxidation, were increased. These data contribute to our understanding of the mechanisms underlying the biological responses to space radiation, and support the involvement of mitochondrial processes in the expression of radiation induced non-targeted effects.

Significantly, they reveal the cross-talk between propagated stressful effects and induced adaptive responses. Together, with the accumulating data in the field, our results may help reduce the uncertainty in the assessment of the health risks to astronauts. They further demonstrate that 'network analyses' is an effective tool towards characterizing the signaling pathways that mediate the long-term biological effects of space radiation.
\end{abstract}

\section{Keywords}

High charge and high energy particles; ionizing radiation; liver; mitochondria; non-targeted responses; oxidative metabolism; space radiation

\section{INTRODUCTION}

During radiotherapy, accidents, or unavoidable exposures in the course of specialized activities, it is more likely that an individual will be partially rather than wholly exposed to

\footnotetext{
*Address for correspondence to this author at Department of Radiology, University of Medicine and Dentistry of New Jersey, New Jersey Medical School Cancer Center, 205 South Orange Avenue, Room - F1212, Newark, NJ 07103, USA; Tel: +1-973-972-5323; Fax:+1-973-972-1865; azzamei@umdnj.edu.
} 
ionizing radiation. However, in early studies of the biological effects of radiation, it has been widely accepted that to elicit an important biological response, the energy from the radiation must be deposited in the nucleus of the targeted cell [1]; that is, bystander cells that neighbor irradiated cells would be unaffected. However, as described here and in the accompanying manuscripts in this issue of the journal [2-6], observations made over the last two decades have clearly indicated that the biological effects of ionizing radiation are not confined to the cells that have been directly targeted by the radiation, but involve a number of non-targeted and delayed effects [7-13]. Whereas intercellular communication of signaling molecules that lead to cell death among irradiated tumor cells, and between irradiated and bystander tumor cells would be beneficial, the transmission of stressful effects from irradiated tumor or normal cells to other normal bystander cells, and the persistence of such effects in their progeny, would have profound implications for long term health risks. Hence, the study of non-targeted effects of ionizing radiation is not only significant to our understanding of intercellular communication, but is also relevant to both clinical and radioprotection issues $[2,3,5]$.

\section{The lonizing Radiation-Induced Bystander Effect}

The ionizing radiation-induced bystander effect has been broadly defined as the occurrence of biological effects in unirradiated cells as a result of exposure of other cells to radiation [14]. Bystander effects have been extensively observed in cell cultures exposed to low fluences of $\alpha$ particles that target only a small fraction of the cells in the population [15]. They were also detected in co-cultures of bystander cells and cells exposed to low linear energy transfer (LET) radiations [16-20] or to high LET radiations besides $\alpha$-particles [21-23], thus highlighting their relevance to radiotherapy, diagnostic radiology, and risk of environmental and occupational exposures [10-12]. Upregulation of stress-responsive proteins, genetic and epigenetic changes, induction of cell cycle checkpoints and cell killing were shown to occur in both irradiated and neighboring bystander cells $[2,3,6,8,10]$. The effects occur in various cell types of human and rodent origin at different stages of growth $[2,9,12,24-26]$. Mechanistic studies have shown that direct and indirect modes of intercellular communication and oxidative metabolism can mediate these effects $[15,27$, 28]; however, the exact molecular steps involved have not been defined [2, 15]. Thus, quantitative and qualitative understanding of these biological effects through system biology approaches should lead to better estimation of health risks [5, 29-31].

In addition to observations in tissue culture, significant radiation-induced bystander effects were detected in 3-dimensional human tissue models [32-34], and in animal experiments [6, 35-37]. With particular relevance to cancer risk, non-targeted oncogenic radiation effects were observed in the cerebellum of radiosensitive mice, when only the rest of their body was $\mathrm{X}$-irradiated [38]. The occurrence of such in vivo stressful non-targeted effects would have significant consequences during particular activities, such as mining or space travel, when often only parts of the human body are irradiated at any one time [39]. In case of deep space travel, it has been estimated that an astronaut's body would be exposed, daily, to very low mean doses of densely ionizing radiations [40]. At the typical doses encountered [41, 42], only a very small fraction of cells in the human body would experience the large ionization events created along the tracks of such radiations [41, 42]. Moreover, the radiation traversals would be separated in tissue location and time [22].

\section{Non-Targeted Effects and Space Radiation}

The health effects of concern from space radiation are those caused by low dose-rate protons and energetic heavy ions for which there is a paucity of data. Due to their high biological effectiveness, high charge and high energy (HZE) particles produce a significant fraction of the effective dose received during missions in space. Whereas photons deposit their energy 
in a rather diffuse pattern, energy deposition by high-LET energetic particles is structured along linear tracks and is far less homogeneous than low LET radiation [43-45]. HZE particles can travel substantial distances in tissue and an enhanced rate of energy loss occurs at the end of their range where high LET values in tissue can be reached (Bragg peak) [46]. Thus, HZE particles likely result in unique biological responses [46-48]. The lack of clear knowledge about these responses, including the induced non-targeted effects [49-51], has been singled out by the US National Academies [52] and recent studies [39] as the most important factor limiting the prediction of radiation risk associated with human space exploration.

During prolonged space travel, astronauts are exposed to ionizing radiation from a variety of sources including galactic cosmic rays, solar protons, and high energy electrons and protons trapped by the earth's magnetic field (Van Allen Belts). Galactic cosmic rays consist mainly of protons, but also include a small component of HZE particles, which due to their high biological effectiveness, produce a significant fraction of the effective dose received during missions in space (reviewed in [22]). Shielding by the earth's thick atmosphere and its magnetic fields provides some protection to astronauts traveling in low earth orbit (e.g. space shuttle and international space station). However, this shielding is lost in deeper interplanetary space and at the Martian surface. Cucinotta et al. [42] calculated that during a mission to Mars, every cell nucleus in an astronaut's body would be hit by a proton or a secondary electron every few days, and by an HZE particle about once a month.

When monolayer cell cultures are exposed to low mean doses from HZE particles, a significant fraction of the cells will not be traversed by a high-LET radiation track [43]. However, some of these cells are irradiated by $\delta$-rays. A $1 \mathrm{GeV} /$ nucleon ${ }^{56} \mathrm{Fe}$ ion generates $\delta$-rays with ranges up to $270 \mu \mathrm{m}$ [53]. The cells traversed by HZE particles may also impart stressful bystander effects on nearby cells $[51,54,55]$. However, the study of in vivo nontargeted effects is only emerging [36-38, 56], in particular in the context of space radiation. The occurrence of delayed stressful effects in targeted and/or non-targeted tissues of animals exposed to particulate radiations found in deep space would have significant relevance to space exploration. Here, we investigate biochemical changes in mitochondria of nontargeted liver of rats that were exposed to energetic titanium ions ( $1100 \mathrm{MeV} /$ nucleon) delivered to the cranial region 20 months earlier. We focused on examining biochemical changes in mitochondria as our earlier tissue culture studies have shown that the functions of these organelles are highly sensitive to ionizing radiation exposures [57, 58], and oxidative metabolism mediates ionizing radiation-induced bystander effects [59-64].

\section{Mitochondria, Oxidative Metabolism and Bystander Effects}

Mitochondria are the organelles that mediate respiration and ATP synthesis in eukaryotic cells. They consume about $90 \%$ of the body's oxygen and participate in numerous indispensable metabolic pathways (e.g. synthesis of heme, nucleotides, lipids, and amino acids) and mediate intracellular homeostasis of inorganic ions [65]. Mitochondrial function is, therefore, essential for the viability of eukaryotic cells.

Mitochondria have inner and outer membranes, a soluble matrix, and an intermembrane space (see scheme in Fig. (1)), and new mitochondria are formed by the growth and division of preexisting organelles. Each cell has many mitochondria, and the amount of mitochondria in the cell is dependent on the particular cell's function. Mitochondria localize in regions where the ATP demand is high; thus, mitochondrial composition varies in different tissues and cell types [66].

The mitochondria's role as "powerhouse of the cell" is fulfilled through aerobic cellular respiration. It is the cell's principal source of energy, and includes the tricarboxylic acid 
(TCA) cycle, the electron transport chain (ETC) that is typically composed of five multisubunit enzymes (complexes I-V), and oxidative phosphorylation. Each of these processes takes place in different regions of the organelle. The TCA cycle occurs in the mitochondrial matrix, and oxidative metabolism of carbohydrates, lipids, and amino acids integrate into the TCA cycle to produce NADH and $\mathrm{FADH}_{2}$. These essential intermediates are electron-rich donors that enter the ETC on the inner mitochondrial membrane for use in ATP production [67]. Ionizing radiation is energetic and penetrating, and may disrupt the formation/ maintenance of some of the macromolecular respiratory complexes, which may be revealed by biochemical approaches, including proteomic approaches. Detailed characterization of persistent changes in the protein composition of mitochondria in irradiated or bystander cells and in their progeny is only emerging. Altered protein expression in mitochondria may affect reactive species level and the overall redox environment of the cell.

A consequence of energy production through oxidative metabolism is the production of reactive oxygen species (ROS) byproducts. The premature leakage of electrons, mainly from complexe I and complex III, and complex II to a minor extent, results in the reduction of $\mathrm{O}_{2}$ to create superoxide $\left(\mathrm{O}_{2}{ }^{-}\right)[68,69]$. Apart from this normal basal level of ROS production, radiation damage to mitochondria, the hub of oxidative metabolism, causes further leakage of electrons from the ETC, and therefore results in excess $\mathrm{O}_{2}{ }^{-}$generation [70]. This occurs in addition to $\mathrm{O}_{2}{ }^{-}$and other chemical species produced during cellular water radiolysis at the time of irradiation, which together results in enduring perturbation of oxidation/ reduction reactions that contribute to maintenance of the cellular redox environment [70, 71]. Thus, though a burst of excess ROS is initially produced at the time of irradiation and is believed to persist for only microseconds or less [72], radiation-induced oxidative stress on the cell may be prolonged due to persistent long-term effects on mitochondrial functions, primarily oxidative metabolism [70], which is likely to involve changes in protein expression in mitochondria.

Short- and long-term radiation-induced cellular oxidative stress could result in damage to mitochondrial DNA (mtDNA) and/or nuclear DNA (nuDNA) coding for mitochondrial ETC subunits as well as the biochemical machinery necessary for the proper expression and assembly of ETC proteins. In fact this possibility has been previously proposed for metabolic oxidative damage that occurs during the aging process $[73,74]$. Compared with nuDNA, mtDNA contains limited repair capability $[75,76]$. Therefore, subsequent to radiation exposure, mtDNA might be preferentially damaged or lost due to oxidative stress with an ensuing decrease in respiratory chain activity and loss of mitochondrial function. Mutations in mtDNA causing disruptions in the proper assembly and/or function of mitochondrial ETCs could lead to an increase in residence time and/or accessibility of reduced components of the ETCs to $\mathrm{O}_{2}$ resulting in an increase in the probability of prooxidant formation [70]. The net consequence being a condition of persistent metabolic oxidative stress that could continue to cause further oxidative damage to critical biological structures long after radiation exposure. Significantly, radiation-induced damage to mtDNA in directly targeted or bystander cells could become a heritable trait and contribute to radiation-induced genomic instability [77]. Insertion of mtDNA in nuDNA may affect the structure of nuclear genome and result in permanent changes in gene expression.

Whereas persistent excess in ROS level in irradiated cells may result from damage to components of the mitochondrial respiratory processes and an effect on plasma membrane oxidases $[78,79]$, it may also result from a disruption in antioxidant enzyme activity. A decrease in the availability of antioxidants or a limited accessibility of the antioxidants to the site of radiation-induced free radical production and oxidative damage contributes to significant damage to cellular macromolecules, including DNA, RNA, proteins, and lipids, 
which may further contribute to genomic instability, cancer, accelerated aging and the development of degenerative diseases [80].

Though most studies have investigated changes in mitochondria functions in irradiated cells [57], here, we examine persistent changes in protein levels in mitochondria of non-targeted liver of Sprague-Dawley rats that were cranially-exposed 20 months earlier to energetic titanium ions (1100 MeV/nucleon). The goal is to investigate changes in proteins associated with metabolic pathways, with the aim of gaining greater understanding of the mechanisms underlying long-term space radiation health risks.

\section{MATERIALS AND METHODS}

Eight-weeks-old male Sprague-Dawley rats were exposed to 0 or $50 \mathrm{cGy}$ from $1100 \mathrm{MeV} /$ nucleon titanium ions (mean LET $\sim 106 \mathrm{keV} / \mu \mathrm{m}$ ) at the NASA Space Radiation Laboratory located at the Brookhaven National Laboratory in Upton, NY, USA. Description of the facility and radiation beam information can be found at http://www.bnl.gov/medical/nasa/LTSF.asp. The rats were housed in AAALAC-accredited facilities and were maintained on a 12-h light/dark cycle in a temperature and humidity controlled room. Food and water were continuously available, and the research protocol was approved by the Institutional Animal Care and Use Committees of all the institutions implicated in the study.

During the irradiation, the rats were placed in well-ventilated plastic restraining tubes that restricted the movement of the animal. The plastic tube was placed perpendicular to the beam and positioned so that the head of the rats was in the center of the beam. As such, the rat's shoulders may have also received some radiation dose. The rats were sacrificed by $\mathrm{CO}_{2}$ asphyxiation 20 months after exposure, liver tissue was harvested, rinsed in buffered Minimal Essential Medium ( $\mathrm{pH}$ 7.4). Liver from three individual rats were pooled from each experimental group and mitochondria was harvested as described [81, 82]. The mitochondrial proteins were isolated [57]; they were purified using Biorad's ReadyPrep 2-D cleanup kit (Catalog \# 163-2130), and subjected to 2-dimensional gel electrophoresis. Briefly, $100 \mu \mathrm{g}$ of proteins in a total of $185 \mu \mathrm{L}$ of the rehydration buffer ( $7 \mathrm{M}$ urea, $2 \mathrm{M}$ thiourea, 4\% CHAPS, $100 \mathrm{mM}$ DTT, $0.2 \%$ Biolytes (pH 5-8), 0.01\% Bromophenol Blue and protease inhibitor) was applied to $11 \mathrm{~cm}$ Bio-Rad ReadyStrip IPG Strips (pH 5-8) for overnight rehydration. First-dimension isoelectric focusing was performed on a Biorad PROTEAN IEF System at the UMDNJ Center for Advanced Proteomics Research (http://njms.umdnj.edu/proweb), as described by the manufacturer for a total focusing time of 75,000 VHrs. The strips were equilibrated with an equilibration solution I ( $6 \mathrm{M}$ urea, $0.375 \mathrm{M}$ Tris-HCl, pH 8.8, 2\% SDS, 20\% glycerol, 2\% (w/v) DTT) for $15 \mathrm{~min}$; they were then further equilibrated with an equilibration solution II (containing $6 \mathrm{M}$ urea, $0.375 \mathrm{M}$ Tris-HCl, $\mathrm{pH} 8.8,2 \% \mathrm{SDS}, 20 \%$ glycerol, 2.5\% (w/v) iodoacetamide) for $15 \mathrm{~min}$ and directly applied to a $12.5 \%$ isocratic SDS-PAGE gel for second dimensional electrophoresis. The resulting gel was then fixed in fixing solution (10\% acetic acid and $40 \%$ ethanol) for 30 min and stained overnight with SYPRO Ruby (Bio-Rad). The gels were destained with destaining solution ( $10 \%$ methanol, $7.5 \%$ acetic acid) for $2 \mathrm{~h}$. After washing with water, they were scanned on a 9400 Typhoon Variable Mode Imager (GE Healthcare) using a green laser $(532 \mathrm{~nm})$ and 610BP30 emission filter. Protein quantitation on SYPRO ruby stained gels was performed by PDQuest 2-D Analysis Software (Bio-Rad) and protein spots whose expression levels significantly changed were cut for mass spectrometric (MS) identification. 


\section{Mass Spectrometry and Protein Identification}

Protein spots from the SYPRO Ruby stained 2-D gel were picked for protein identification. The gel bands were diced into $1 \mathrm{~mm}^{3}$ pieces and washed with $30 \%$ acetonitrile (ACN) in 50 $\mathrm{mM}$ ammonium bicarbonate prior to DTT reduction and iodoacetamide alkylation. Trypsin was used for digestion at $37^{\circ} \mathrm{C}$ overnight. The resulting peptides were extracted with $30 \mu 1$ of $1 \%$ trifluoracetic acid (TFA) followed by $\mathrm{C}_{18}$ ZipTip desalting. For the MS analysis, the peptides were mixed with $7 \mathrm{mg} / \mathrm{ml} \alpha$-cyano-4-hydroxy-cinnamic acid matrix (in $60 \%$ CAN) in a 1:1 ratio and spotted onto a matrix assisted laser desorption/ionization (MALDI) plate. The peptides were analyzed on a 4800 MALDI TOF/TOF analyzer (Applied Biosystem, Framingham, MA). Mass spectra $(\mathrm{m} / \mathrm{z} 880-3,200)$ were acquired in positive ion reflector mode. Fifteen most intense ions were selected for subsequent MS/MS sequencing analysis in $1 \mathrm{kV}$ mode. Protein identification was performed by searching the combined MS and MS/ MS spectra against the NCBI rat sequence database (ftp://ftp.ncbi.nih.gov/blast/db/FASTA) using a local MASCOT search engine (V. 1.9) on a GPS (V. 3.5, ABI) server. Protein containing at least two peptides with Confidence Interval (C. I.) values of no less than $95 \%$ was considered being identified.

\section{RESULTS AND DISCUSSION}

The transfer of radiation energy to living tissues causes ionization of atoms and molecules and breaks chemical bonds, which initiates a series of biochemical and molecular signaling events that culminate in transient or permanent physiological changes [83]. In evaluating these changes, it had been traditionally thought that the important biological effects were confined to the targeted cells, and were a result of the direct interaction of the radiation with the DNA of these cells $[8,9]$. It was generally presumed that no effect would be expected in cells in the population that receive no direct radiation exposure. However, since the landmark paper by Nagasawa and Little [14], the evidence for the existence of non-targeted/ bystander effects of radiation has accumulated and has been observed in many laboratories (reviewed in [11, 84, 85] and in [2,3] in this issue). Whereas, radiation-induced bystander effects have been well characterized in vitro, their expression in vivo is less clear, particularly in the context of space radiation. Our ongoing studies (not shown) with rodents that received partial body irradiation from HZE particles such as those found in deep space have clearly shown that mitochondrial functions are impaired in different non-targeted tissues. For example, import of proteins that localize in the mitochondrial matrix was greatly reduced in non-targeted liver of cranially-irradiated rats. The effect was coupled with extensive and persistent protein carbonylation. To gain understanding of the mechanisms underlying these changes, we examined alterations in protein levels in mitochondria of liver of rats that were exposed to $50 \mathrm{cGy}$ from ${ }^{48} \mathrm{Ti}(1100 \mathrm{MeV} /$ nucleon, mean LET $\sim 106 \mathrm{keV} /$ $\mu \mathrm{m})$ targeted to the cranial region.

Two-dimensional gel analyses revealed that the level of several proteins was significantly altered as shown in Table (1). In particular, acetyl-Coenzyme A acyltransferase 2, hydroxyacyl-Coenzyme A dehydrogenase/3-ketoacyl-Coenzyme A thiolase/enoylCoenzyme A hydratase (trifunctional protein), alpha subunit were found to be downregulated by at least 2.5 fold. All these proteins are involved in fatty acid elongation in mitochondria (Fig. (2)). Fatty acid synthesis in mitochondria occurs by an acetyl-CoAdependent elongation of fatty acids [86-88]. The pathway involves elongation of either palmitate or other dietary fatty acids to give rise to longer fatty acids. Fatty acid elongation is important to store energy and to synthesize lipids that are important for cellular functions, including membrane components [89]. These finding suggest that irradiation results in deficiency in the ability of certain non-targeted tissues to synthesize and store fatty acids. Our ongoing studies are investigating whether this deficiency occurs also in the irradiated or 
other non-irradiated tissues, and whether protein degradation is involved in the reduced expression levels.

Further, relative to control, the expression level of DNAJC3, DnaJ (Hsp40) homolog, subfamily C, member 3, also known as protein kinase inhibitor p58, was increased by 1.6 fold in the non-targeted liver of the irradiated rats (Table (1)). DNAJC3 is involved in the endoplasmic reticulum stress response. In particular, it is also a target of $\mathrm{Nrf2}$, a critical transcription factor for mediating amplification of the mammalian defense system against environmental stresses (Fig. (3)). The Nrf2 protein is known to be a key regulator of the response to oxidative stress $[90,91]$. It acts as a nuclear transcription factor that controls the expression and coordinated induction of a battery of defensive genes encoding detoxifying enzymes and antioxidant proteins. Thus it represents a mechanism of critical importance for cellular protection and cell survival [92]. Similarly, the expression level of carboxylesterase 1 (monocyte/macrophage serine esterase 1) was found to be increased by 3.6 fold.

Carboxylesterase 1 plays a role in detoxification in the lung and/or protection of the central nervous system from ester or amide compounds [93], and carboxylesterase deficiency may be associated with non-Hodgkin lymphoma or B-cell lymphocytic leukemia [94].

Furthermore, carboxylesterase 1 is a target of pregnane X receptor (PXR) [95], a key regulator of the body's adaptive defense mechanism against toxic substances including foreign chemicals (xenobiotics). Investigation of the inter-relationship between adaptive and bystander responses has been proposed as critical to understanding the health risks of lowlevel radiation exposures $[85,96]$. Together, our findings provide novel mechanistic evidence for the cross-talk between these phenomena and show that although stressful effects may be propagated from irradiated to non-irradiated tissues, key pathways are activated to cope with the induced stress. Significantly, in terms of evaluating the health risks of exposure to space radiation, our results indicate that these changes persist and are observed several months after the irradiation.

\section{CONCLUSIONS}

Our results support the concept that ionizing radiation interferes with cellular functions at all levels of the organism's organization, including the targeted and non-targeted tissues. They challenge the traditional paradigm that the important biological effects of ionizing radiation are a result of DNA damage by its direct interaction with the nucleus [8]. They indicate that metabolism is implicated in radiation-induced non-targeted effects. However, clear evidence explaining how these events occur is still lacking.

Our data show that ionizing radiation induces alterations, by non-targeted effects, in the protein composition of mitochondria, the organelles where most reactions involved in oxidative metabolism occur. The analyses of changes in protein levels in mitochondria of non-targeted liver of rats that received partial body irradiation from energetic titanium ions has shown regulation of proteins involved in signaling events that mediate both stressful non-targeted effects and protective adaptive responses. Significantly, the data cement the concept that in vivo space radiation-induced non-targeted effects do indeed exist [39, 97]. Importantly, they show that these effects persist and are observed long after the exposure (20 months). They reveal the cross-talk between late non-targeted stressful effects (Fig. (2)) and protective adaptive responses (Fig. (3)).

Gene expression is regulated at multiple levels [6], and elucidating the molecular events leading to the altered expression of the proteins investigated in this study (Table (1)) should lead to greater understanding of the mechanisms underlying the long-term effects of space radiation on health and disease. The available data bases on long-term effects on astronauts' health are likely to remain extremely limited in the near future; therefore, understanding of 
the mechanisms underlying the biological responses to energetic proton- and heavy ionexposures will help reduce the uncertainty in the assessment of the health risks to astronauts (and public travelers in the future) from low-level exposure to space radiation [98]. Expansion of these studies to early and late time points after exposure to acute and protracted particulate space radiations should increase our understanding of the signaling pathways involved. It may also guide the formulation of interventional strategies, including dietary antioxidants, substrates for the regeneration of reducing equivalents necessary for antioxidant pathways and genetic manipulations [98-102]. Finally, our study shows that network analyses is indeed an effective tool towards characterizing the signaling pathways that mediate the biological effects of space radiation.

\section{Acknowledgments}

We thank Drs. Adam Rusek, Michael Sivertz, I-Hung Chiang, Peter Guida and their colleagues for support provided for the experiments at the NASA Space Radiation Laboratory. This research was supported by Grants from NASA to BMR and EIA. HL is supported by a UMDNJ Neuroproteomics grant from the NIH.

\section{References}

1. Zirkle RE, Bloom W. Irradiation of parts of individual cells. Science. 1953; 117:487-493. [PubMed: 13056589]

2. Hamada N, Maeda M, Otsuka K, Tomita M. Signaling pathways underpinning the manifestations of ionizing radiation-induced bystander effects. Curr Mol Pharmacol. 2011; 4 in this issue. [PubMed: 21143186]

3. Hei TK, Zhou H, Chai Y, Ponnaiya B, Ivanov VN. Radiation induced non-targeted response: mechanism and potential clinical implications. Curr Mol Pharmacol. 2011; 4 in this issue. [PubMed: 21143185]

4. Matsumoto H, Tomita M, Otsuka K, Hatashita M, Hamada N. Nitric oxide is a key molecule serving as a bridge between radiation-induced bystander and adaptive responses. Curr Mol Pharmacol. 2011; 4 in this issue. [PubMed: 21143183]

5. Morgan WF. Communicating non-targeted effects of radiation to achieve adaptive homeostasis in tissues. Curr Mol Pharmacol. 2011; 4 in this issue. [PubMed: 21143182]

6. Tamminga J, Kovalchuk O. Role of DNA damage and epigenetic DNA methylation changes in radiation-induced genomic instability and bystander effects in germline in vivo. Curr Mol Pharmacol. 2011; 4 in this issue. [PubMed: 21143184]

7. Hall EJ, Hei TK. Genomic instability and bystander effects induced by high-LET radiation. Oncogene. 2003; 22:7034-7042. [PubMed: 14557808]

8. Little JB. Genomic instability and bystander effects: a historical perspective. Oncogene. 2003; 22:6978-6987. [PubMed: 14557801]

9. Morgan WF. Non-targeted and delayed effects of exposure to ionizing radiation: II. Radiationinduced genomic instability and bystander effects in vivo, clastogenic factors and transgenerational effects. Radiat Res. 2003; 159:581-596. [PubMed: 12710869]

10. Mothersill C, Seymour CB. Radiation-induced bystander effects--implications for cancer. Nat Rev Cancer. 2004; 4:158-164. [PubMed: 14964312]

11. Prise KM, O’Sullivan JM. Radiation-induced bystander signalling in cancer therapy. Nat Rev Cancer. 2009; 9:351-360. [PubMed: 19377507]

12. Azzam EI, Little JB. The radiation-induced bystander effect: evidence and significance. Hum Exp Toxicol. 2004; 23:61-65. [PubMed: 15070061]

13. Hamada N, Matsumoto H, Hara T, Kobayashi Y. Intercellular and intracellular signaling pathways mediating ionizing radiation-induced bystander effects. J Radiat Res (Tokyo). 2007; 48:87-95.

14. Nagasawa H, Little JB. Induction of sister chromatid exchanges by extremely low doses of alphaparticles. Cancer Res. 1992; 52:6394-6396. [PubMed: 1423287]

15. Azzam EI, de Toledo SM, Little JB. Oxidative metabolism, gap junctions and the ionizing radiation-induced bystander effect. Oncogene. 2003; 22:7050-7057. [PubMed: 14557810] 
16. Bishayee A, Rao DV, Howell RW. Evidence for pronounced bystander effects caused by nonuniform distributions of radioactivity using a novel three-dimensional tissue culture model. Radiat Res. 1999; 152:88-97. [PubMed: 10428683]

17. Gerashchenko BI, Howell RW. Cell proximity is a prerequisite for the proliferative response of bystander cells co-cultured with cells irradiated with gamma-rays. Cytometry. 2003; 56A:71-80.

18. Mothersill C, Seymour C. Survival of human epithelial cells irradiated with cobalt 60 as microcolonies or single cells. Int J Radiat Biol. 1997; 72:597-606. [PubMed: 9374439]

19. Xue LY, Butler NJ, Makrigiorgos GM, Adelstein SJ, Kassis AI. Bystander effect produced by radiolabeled tumor cells in vivo. Proc Natl Acad Sci U S A. 2002; 99:13765-13770. [PubMed: 12368480]

20. Persaud R, Zhou H, Baker SE, Hei TK, Hall EJ. Assessment of low linear energy transfer radiation-induced bystander mutagenesis in a three-dimensional culture model. Cancer Res. 2005; 65:9876-9882. [PubMed: 16267011]

21. Brooks AL, Retherford JC, McClellan RO. Effect of 239PuO2 particle number and size on the frequency and distribution of chromosome aberrations in the liver of the Chinese hamster. Radiat Res. 1974; 59:693-709. [PubMed: 4428016]

22. Held KD. Effects of low fluences of radiations found in space on cellular systems. Int J Radiat Biol. 2009; 85:379-390. [PubMed: 19382021]

23. Matsumoto H, Hayashi S, Hatashita M, Shioura H, Ohtsubo T, Kitai R, Ohnishi T, Yukawa O, Furusawa Y, Kano E. Induction of radioresistance to accelerated carbon-ion beams in recipient cells by nitric oxide excreted from irradiated donor cells of human glioblastoma. Int J Radiat Biol. 2000; 76:1649-1657. [PubMed: 11133047]

24. Azzam EI, de Toledo SM, Little JB. Expression of CONNEXIN43 is highly sensitive to ionizing radiation and environmental stresses. Cancer Res. 2003; 63:7128-7135. [PubMed: 14612506]

25. Barcellos-Hoff MH, Brooks AL. Extracellular signaling through the microenvironment: a hypothesis relating carcinogenesis, bystander effects, and genomic instability. Radiat Res. 2001; 156:618-627. [PubMed: 11604083]

26. Mothersill C, Seymour C. Radiation-induced bystander effects: past history and future directions. Radiat Res. 2001; 155:759-767. [PubMed: 11352757]

27. Azzam EI, de Toledo SM, Little JB. Direct evidence for the participation of gap-junction mediated intercellular communication in the transmission of damage signals from alpha-particle irradiated to non-irradiated cells. Proc Natl Acad Sci U S A. 2001; 98:473-478. [PubMed: 11149936]

28. Zhou HN, Suzuki M, Randers-Pehrson R, Chen G, Trosko J, Vannais D, Waldren CA, Hall EJ, Hei TK. Radiation risk at low doses may be greater than we thought. Proc Natl Acad Sci USA. 2001; 98:14410-14415.

29. Chaudhry MA. Bystander effect: biological endpoints and microarray analysis. Mutat Res. 2006; 597:98-112. [PubMed: 16414093]

30. Ivanov VN, Zhou H, Ghandhi SA, Karasic TB, Yaghoubian B, Amundson SA, Hei TK. Radiationinduced bystander signaling pathways in human fibroblasts: a role for interleukin-33 in the signal transmission. Cell Signal. 22:1076-1087. [PubMed: 20206688]

31. Iwakawa M, Hamada N, Imadome K, Funayama T, Sakashita T, Kobayashi Y, Imai T. Expression profiles are different in carbon ion-irradiated normal human fibroblasts and their bystander cells. Mutat Res. 2008; 642:57-67. [PubMed: 18538798]

32. Belyakov OV, Mitchell SA, Parikh D, Randers-Pehrson G, Marino SA, Amundson SA, Geard CR, Brenner DJ. Biological effects in unirradiated human tissue induced by radiation damage up to 1 mm away. Proc Natl Acad Sci U S A. 2005; 102:14203-14208. [PubMed: 16162670]

33. Sedelnikova OA, Nakamura A, Kovalchuk O, Koturbash I, Mitchell SA, Marino SA, Brenner DJ, Bonner WM. DNA double-strand breaks form in bystander cells after microbeam irradiation of three-dimensional human tissue models. Cancer Res. 2007; 67:4295-4302. [PubMed: 17483342]

34. Kovalchuk O, Zemp FJ, Filkowski J, Altamirano A, Dickey JS, Jenkins-Baker G, Marino SA, Brenner DJ, Bonner WM, Sedelnikova OA. microRNAome changes in bystander threedimensional human tissue models suggest priming of apoptotic pathways. Carcinogenesis. [PubMed: 20643754] 
35. Lorimore SA, Coates PJ, Scobie GE, Milne G, Wright EG. Inflammatory-type responses after exposure to ionizing radiation in vivo: a mechanism for radiation-induced bystander effects? Oncogene. 2001; 20:7085-7095. [PubMed: 11704832]

36. Koturbash I, Kutanzi K, Hendrickson K, Rodriguez-Juarez R, Kogosov D, Kovalchuk O. Radiation-induced bystander effects in vivo are sex specific. Mutat Res. 2008; 642:28-36. [PubMed: 18508093]

37. Chai, Y. Radiation Induced COX-2 Expression and Mutagenesis in Non-Targeted Lung Tissues of gpt Delta Transgenic Mice. Columbia University; New York: 2010.

38. Mancuso M, Pasquali E, Leonardi S, Tanori M, Rebessi S, Di Majo V, Pazzaglia S, Toni MP, Pimpinella M, Covelli V, Saran A. Oncogenic bystander radiation effects in Patched heterozygous mouse cerebellum. Proc Natl Acad Sci U S A. 2008; 105:12445-12450. [PubMed: 18711141]

39. Cucinotta FA, Chappell LJ. Non-targeted effects and the dose response for heavy ion tumor induction. Mutat Res. 687:49-53. [PubMed: 20085778]

40. Blakely EA. Biological effects of cosmic radiation: deterministic and stochastic. Health Phys. 2000; 79:495-506. [PubMed: 11045523]

41. Charlton DE, Sephton R. A relationship between microdosimetric spectra and cell survival for high-LET irradiation. Int J Radiat Biol. 1991; 59:447-457. [PubMed: 1671694]

42. Cucinotta F, Nikjoo H, Goodhead DT. The effect of delta rays on the number of particle traversals per cell in laboratory and space exposures. Radiat Res. 1998; 150:115-119. [PubMed: 9650608]

43. Brenner DJ, Elliston CD. The potential impact of bystander effects on radiation risks in a Mars mission. Radiat Res. 2001; 156:612-617. [PubMed: 11604082]

44. Ballarini F, Ottolenghi A. A model of chromosome aberration induction: applications to space research. Radiat Res. 2005; 164:567-570. [PubMed: 16187789]

45. Cucinotta FA, Wu H, Shavers MR, George K. Radiation dosimetry and biophysical models of space radiation effects. Gravit Space Biol Bull. 2003; 16:11-18. [PubMed: 12959127]

46. Nelson GA. Fundamental space radiobiology. Gravitational and Space Biology Bulletin. 2003; 16:29-36. [PubMed: 12959129]

47. Ponomarev AL, Brenner D, Hlatky LR, Sachs RK. A polymer, random walk model for the sizedistribution of large DNA fragments after high linear energy transfer radiation. Radiat Environ Biophys. 2000; 39:111-120. [PubMed: 10929379]

48. Ponomarev AL, Cucinotta FA. Chromatin loops are responsible for higher counts of small DNA fragments induced by high-LET radiation, while chromosomal domains do not affect the fragment sizes. Int J Radiat Biol. 2006; 82:293-305. [PubMed: 16690597]

49. Fournier C, Barberet P, Pouthier T, Ritter S, Fischer B, Voss KO, Funayama T, Hamada N, Kobayashi Y, Taucher-Scholz G. No evidence for DNA and early cytogenetic damage in bystander cells after heavy-ion microirradiation at two facilities. Radiat Res. 2009; 171:530-540. [PubMed: 19580488]

50. Harada K, Nonaka T, Hamada N, Sakurai H, Hasegawa M, Funayama T, Kakizaki T, Kobayashi Y, Nakano T. Heavy-ion-induced bystander killing of human lung cancer cells: role of gap junctional intercellular communication. Cancer Sci. 2009; 100:684-688. [PubMed: 19469013]

51. Yang H, Anzenberg V, Held KD. The time dependence of bystander responses induced by iron-ion radiation in normal human skin fibroblasts. Radiat Res. 2007; 168:292-298. [PubMed: 17705636]

52. Managing Space Radiation Risk in the New Era of Space Exploration. The National Academies Press; Washington, D.C.: 2008.

53. Metting NF, Rossi HH, Braby LA, Kliauga PJ, Howard J, Zaider M, Schimmerling W, Wong M, Rapkin M. Microdosimetry near the trajectory of high-energy heavy ions. Radiat Res. 1988; 116:183-195. [PubMed: 3186931]

54. Shao C, Aoki M, Furusawa Y. Bystander effect on cell growth stimulation in neoplastic HSGc cells induced by heavy-ion irradiation. Radiat Environ Biophys. 2003 [PubMed: 12920531]

55. Shao C, Furusawa Y, Aoki M, Matsumoto H, Ando K. Nitric oxide-mediated bystander effect induced by heavy-ions in human salivary gland tumour cells. Int J Radiat Biol. 2002; 78:837-844. [PubMed: 12428924]

56. Koturbash I, Loree J, Kutanzi K, Koganow C, Pogribny I, Kovalchuk O. In vivo bystander effect: cranial X-irradiation leads to elevated DNA damage, altered cellular proliferation and apoptosis, 
and increased p53 levels in shielded spleen. Int J Radiat Oncol Biol Phys. 2008; 70:554-562. [PubMed: 18207032]

57. Pandey BN, Gordon DA, Pain D, Azzam EI. Normal human fibroblasts exposed to high or low dose ionizing radiation: Differential effects on mitochondrial protein import and membrane potential. Antioxid Redox Signal. 2006; 8:1253-1261. [PubMed: 16910773]

58. de Toledo SM, Asaad N, Venkatachalam P, Li L, Spitz DR, Azzam EI. Adaptive responses to lowdose/low-dose-rate gamma rays in normal human fibroblasts: The role of growth architecture and oxidative metabolism. Radiat Res. 2006; 166:849-857. [PubMed: 17149977]

59. Azzam EI, de Toledo SM, Spitz DR, Little JB. Oxidative metabolism modulates signal transduction and micronucleus formation in bystander cells from alpha-particle-irradiated normal human fibroblast cultures. Cancer Res. 2002; 62:5436-5442. [PubMed: 12359750]

60. Hei TK, Zhou H, Ivanov VN, Hong M, Lieberman HB, Brenner DJ, Amundson SA, Geard CR. Mechanism of radiation-induced bystander effects: a unifying model. J Pharm Pharmacol. 2008; 60:943-950. [PubMed: 18644187]

61. Zhou H, Ivanov VN, Gillespie J, Geard CR, Amundson SA, Brenner DJ, Yu Z, Lieberman HB, Hei TK. Mechanism of radiation-induced bystander effect: role of the cyclooxygenase-2 signaling pathway. Proc Natl Acad Sci U S A. 2005; 102:14641-14646. [PubMed: 16203985]

62. Chen S, Zhao Y, Zhao G, Han W, Bao L, Yu KN, Wu L. Up-regulation of ROS by mitochondriadependent bystander signaling contributes to genotoxicity of bystander effects. Mutat Res. 2009; 666:68-73. [PubMed: 19393669]

63. Maguire P, Mothersill C, Seymour C, Lyng FM. Medium from irradiated cells induces dosedependent mitochondrial changes and BCL2 responses in unirradiated human keratinocytes. Radiat Res. 2005; 163:384-390. [PubMed: 15799693]

64. Kanasugi Y, Hamada N, Wada S, Funayama T, Sakashita T, Kakizaki T, Kobayashi Y, Takakura K. Role of DNA-PKcs in the bystander effect after low- or high-LET irradiation. Int J Radiat Biol. 2007; 83:73-80. [PubMed: 17357428]

65. Tzagoloff, A. Mitochondria Cellular Organelles Series. Plenum Press; New York: 1982.

66. Scheffler, IE. Mitochondria. 2. Wiley-Liss; Hoboken, NJ: 2008.

67. Champe, PC.; Harvey, RA.; Ferrier, DR. Biochemistry. 4. Wolters Kluwer Health/Lippincott Williams \& Wilkins; Philadelphia: 2008.

68. Boveris A. Mitochondrial production of superoxide radical and hydrogen peroxide. Adv Exp Med Biol. 1977; 78:67-82. [PubMed: 197811]

69. Cadenas E, Davies KJ. Mitochondrial free radical generation, oxidative stress, and aging. Free Radic Biol Med. 2000; 29:222-230. [PubMed: 11035250]

70. Spitz DR, Azzam EI, Li JJ, Gius D. Metabolic oxidation/reduction reactions and cellular responses to ionizing radiation: a unifying concept in stress response biology. Cancer Metastasis Rev. 2004; 23:311-322. [PubMed: 15197331]

71. Schafer FQ, Buettner GR. Redox environment of the cell as viewed through the redox state of the glutathione disulfide/glutathione couple. Free Radic Biol Med. 2001; 30:1191-1212. [PubMed: 11368918]

72. Muroya Y, Plante I, Azzam EI, Meesungnoen J, Katsumura Y, Jay-Gerin JP. High-LET ion radiolysis of water: visualization of the formation and evolution of ion tracks and relevance to the radiation-induced bystander effect. Radiat Res. 2006; 165:485-491. [PubMed: 16579662]

73. Beckman KB, Ames BN. The free radical theory of aging matures. Physiol Rev. 1998; 78:547581. [PubMed: 9562038]

74. Lu CY, Lee HC, Fahn HJ, Wei YH. Oxidative damage elicited by imbalance of free radical scavenging enzymes is associated with large-scale mtDNA deletions in aging human skin. Mutat Res. 1999; 423:11-21. [PubMed: 10029667]

75. Zastawny TH, Dabrowska M, Jaskolski T, Klimarczyk M, Kulinski L, Koszela A, Szczesniewicz M, Sliwinska M, Witkowski P, Olinski R. Comparison of oxidative base damage in mitochondrial and nuclear DNA. Free Radic Biol Med. 1998; 24:722-725. [PubMed: 9586801]

76. Wallace DC. Diseases of the mitochondrial DNA. Annu Rev Biochem. 1992; 61:1175-1212. [PubMed: 1497308] 
77. Gaziev AI, Shaikhaev GO. Ionizing radiation can activate the insertion of mitochondrial DNA fragments in the nuclear genome. Radiats Biol Radioecol. 2007; 47:673-683. [PubMed: 18380326]

78. Burdon RH. Control of cell proliferation by reactive oxygen species. Biochem Soc Trans. 1996; 24:1028-1032. [PubMed: 8968506]

79. Kamata H, Hirata H. Redox regulation of cellular signalling. Cell Signal. 1999; 11:1-14. [PubMed: 10206339]

80. Finkel T, Holbrook NJ. Oxidants, oxidative stress and the biology of ageing. Nature. 2000; 408:239-247. [PubMed: 11089981]

81. Johnston AJ, Hoogenraad J, Dougan DA, Truscott KN, Yano M, Mori M, Hoogenraad NJ, Ryan MT. Insertion and assembly of human tom7 into the preprotein translocase complex of the outer mitochondrial membrane. J Biol Chem. 2002; 277:42197-42204. [PubMed: 12198123]

82. Frezza C, Cipolat S, Scorrano L. Organelle isolation: functional mitochondria from mouse liver, muscle and cultured fibroblasts. Nat Protoc. 2007; 2:287-295. [PubMed: 17406588]

83. Hall, EJ. Radiobiology for the Radiologist. 5. J. B. Lippincott Co.; Philadelphia: 2000.

84. Morgan WF. Non-targeted and delayed effects of exposure to ionizing radiation: I. Radiationinduced genomic instability and bystander effects in vitro. Radiat Res. 2003; 159:567-580. [PubMed: 12710868]

85. Matsumoto H, Hamada N, Takahashi A, Kobayashi Y, Ohnishi T. Vanguards of paradigm shift in radiation biology: radiation-induced adaptive and bystander responses. J Radiat Res (Tokyo). 2007; 48:97-106.

86. Abu-Elheiga L, Matzuk MM, Abo-Hashema KA, Wakil SJ. Continuous fatty acid oxidation and reduced fat storage in mice lacking acetyl-CoA carboxylase 2. Science. 2001; 291:2613-2616. [PubMed: 11283375]

87. Wakil SJ. Lipid metabolism. Annu Rev Biochem. 1962; 31:369-406. [PubMed: 14004468]

88. Wakil SJ, Abu-Elheiga LA. Fatty acid metabolism: target for metabolic syndrome. J Lipid Res. 2009; 50(Suppl):S138-143. [PubMed: 19047759]

89. Wang C, Rajput S, Watabe K, Liao DF, Cao D. Acetyl-CoA carboxylase-a as a novel target for cancer therapy. Front Biosci (Schol Ed). 2:515-526.

90. Kwak MK, Itoh K, Yamamoto M, Kensler TW. Enhanced expression of the transcription factor $\mathrm{Nrf} 2$ by cancer chemopreventive agents: role of antioxidant response element-like sequences in the nrf2 promoter. Mol Cell Biol. 2002; 22:2883-2892. [PubMed: 11940647]

91. Kwak MK, Wakabayashi N, Itoh K, Motohashi H, Yamamoto M, Kensler TW. Modulation of gene expression by cancer chemopreventive dithiolethiones through the Keap1-Nrf2 pathway Identification of novel gene clusters for cell survival. J Biol Chem. 2003; 278:8135-8145. [PubMed: 12506115]

92. Kaspar JW, Niture SK, Jaiswal AK. Nrf2:INrf2 (Keap1) signaling in oxidative stress. Free Radic Biol Med. 2009; 47:1304-1309. [PubMed: 19666107]

93. Wheelock CE, Phillips BM, Anderson BS, Miller JL, Miller MJ, Hammock BD. Applications of carboxylesterase activity in environmental monitoring and toxicity identification evaluations (TIEs). Rev Environ Contam Toxicol. 2008; 195:117-178. [PubMed: 18418956]

94. Yamada S, Richardson K, Tang M, Halaschek-Wiener J, Cook VJ, Fitzgerald JM, Elwood K, Marra F, Brooks-Wilson A. Genetic variation in carboxylesterase genes and susceptibility to isoniazid-induced hepatotoxicity. Pharmacogenomics J. [PubMed: 20195289]

95. Yang J, Yan B. Photochemotherapeutic agent 8-methoxypsoralen induces cytochrome P450 3A4 and carboxylesterase HCE2: evidence on an involvement of the pregnane X receptor. Toxicol Sci. 2007; 95:13-22. [PubMed: 17003103]

96. Kadhim MA, Moore SR, Goodwin EH. Interrelationships amongst radiation-induced genomic instability, bystander effects, and the adaptive response. Mutat Res. 2004; 568:21-32. [PubMed: 15530536]

97. Turker MS, Connolly L, Dan C, Lasarev M, Gauny S, Kwoh E, Kronenberg A. Comparison of autosomal mutations in mouse kidney epithelial cells exposed to iron ions in situ or in culture. Radiat Res. 2009; 172:558-566. [PubMed: 19883223] 
98. Durante M, Cucinotta FA. Heavy ion carcinogenesis and human space exploration. Nat Rev Cancer. 2008; 8:465-472. [PubMed: 18451812]

99. Kennedy AR, Davis JG, Carlton W, Ware JH. Effects of dietary antioxidant supplementation on the development of malignant lymphoma and other neoplastic lesions in mice exposed to proton or iron-ion radiation. Radiat Res. 2008; 169:615-625. [PubMed: 18494549]

100. Rabin BM, Shukitt-Hale B, Joseph J, Todd P. Diet as a factor in behavioral radiation protection following exposure to heavy particles. Gravit Space Biol Bull. 2005; 18:71-77. [PubMed: 16038094]

101. Shukitt-Hale B, Carey AN, Jenkins D, Rabin BM, Joseph JA. Beneficial effects of fruit extracts on neuronal function and behavior in a rodent model of accelerated aging. Neurobiol Aging. 2007; 28:1187-1194. [PubMed: 16837106]

102. Simons AL, Mattson DM, Dornfeld K, Spitz DR. Glucose deprivation-induced metabolic oxidative stress and cancer therapy. J Cancer Res Ther. 2009; 5(Suppl 1):S2-6. [PubMed: 20009288]

\section{ABBREVIATIONS}

2-D

AAALAC

ACN

ATP

CHAPS

CoA

DNAJC3

DTT

ETC

FADH $_{2}$

HZE

IEF

IPG

LET

MALDI

MASCOT

MS

mtDNA

NADH

NCBI

Nrf2

nUDNA

ROS

SDS-PAGE
Two-dimensional

Association for assessment and accreditation of laboratory animal care international

Acetonitrile

Adenosine triphosphate

3[(3-Cholamidopropyl)dimethylammonio]-propanesulfonic acid

Coenzyme A

DnaJ (Hsp40) homolog, subfamily C, member 3

Dithiothreitol

Electron transport chain

Flavin adenine dinucleotide (reduced form)

High charge and high energy

Isoelectric focusing

Immobilized $\mathrm{pH}$ gradient

Linear energy transfer

Matrix assisted laser desorption/ionization

Modular approach to software construction operation and test

Mass spectrometry

Mitochondrial DNA

Nicotinamide adenine dinucleotide (reduced form)

National center for biotechnology information

Nuclear factor (erythroid-derived 2)-like 2

Nuclear DNA

Reactive oxygen species

Sodium dodecyl sulfate-polyacrylamide gel electrophoresis 


$\begin{array}{ll}\text { TCA } & \text { Tricarboxylic acid cycle } \\ \text { TOF } & \text { Time of flight }\end{array}$




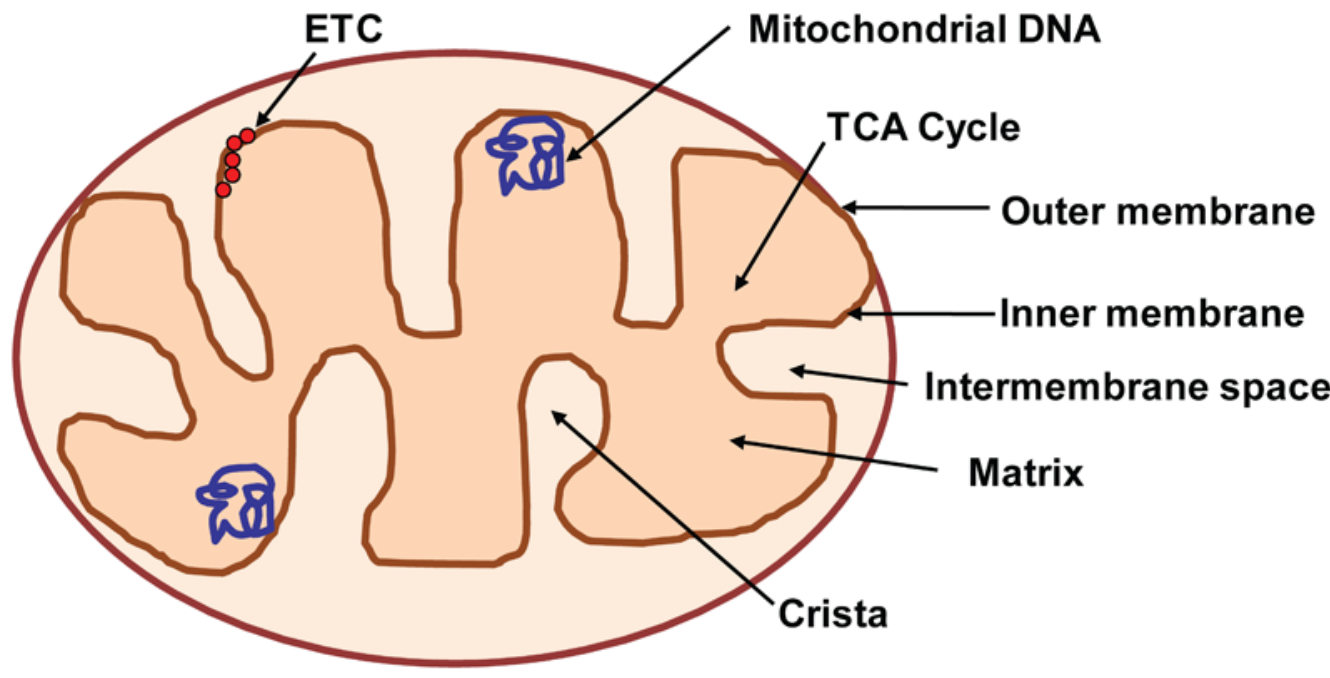

Fig. (1).

A simplified schematic of the structure of the mitochondrion 


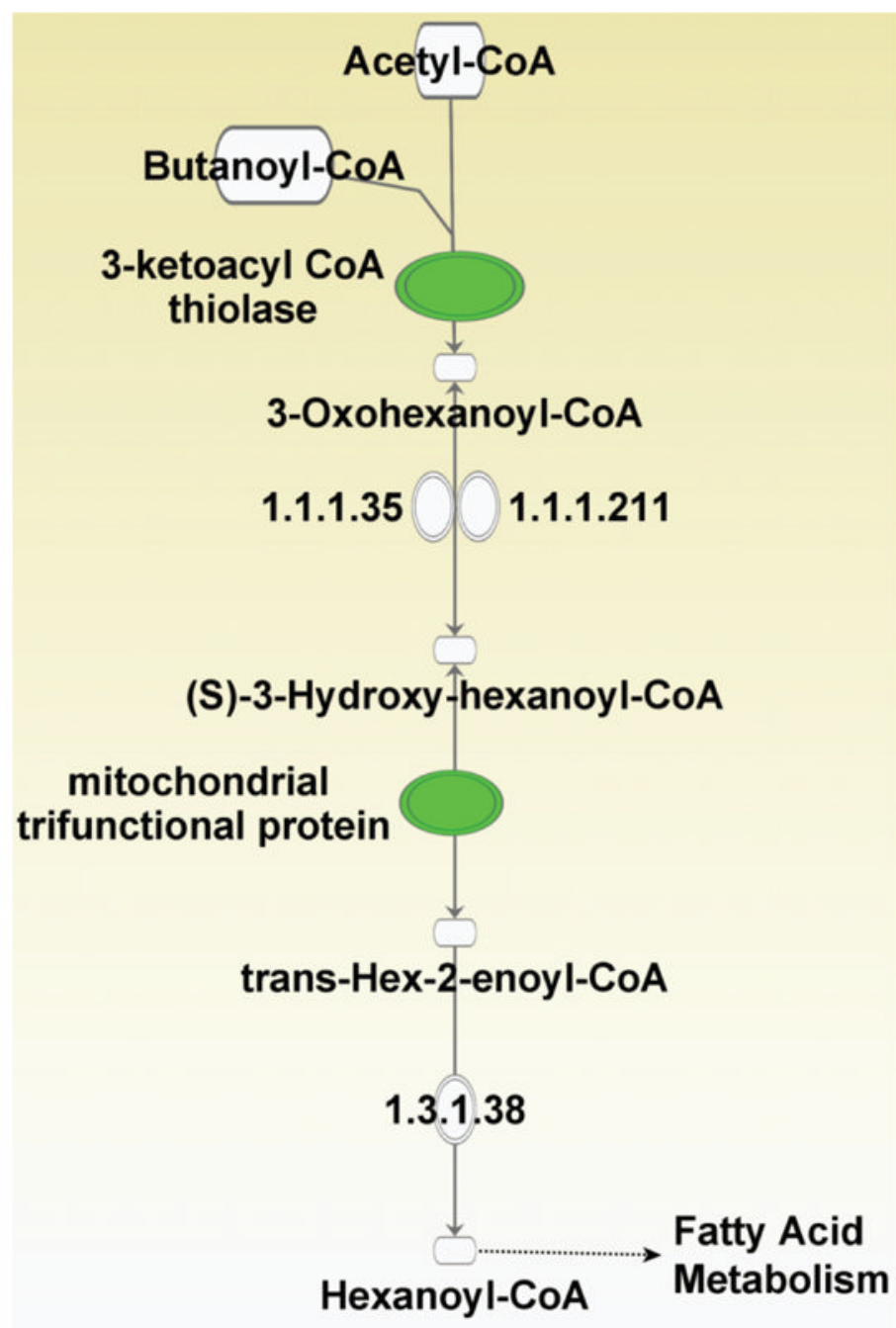

Fig. (2).

Proteins down-regulated in mitochondria of non-targeted liver of rats whose head was exposed 20 months earlier to $1100 \mathrm{MeV} /$ nucleon titanium ions participate in fatty acid elongation in mitochondria. (The down-regulated proteins (highlighted in green) are 3ketoacyl CoA thiolase and mitochondrial trifunctional protein alpha subunit). 


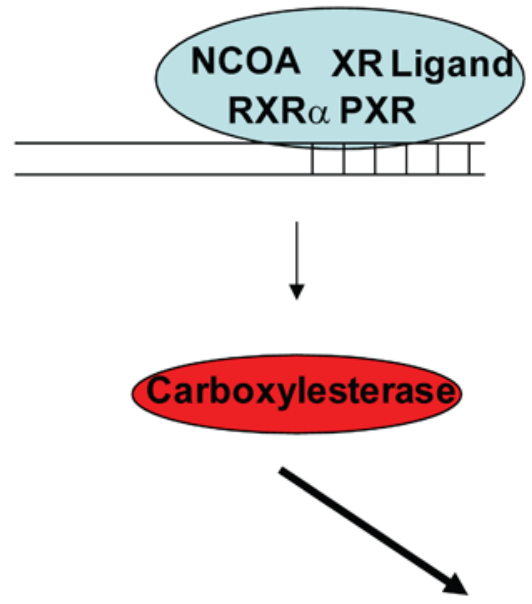

\section{lonizing Radiation}

$\downarrow$

Cell Survival

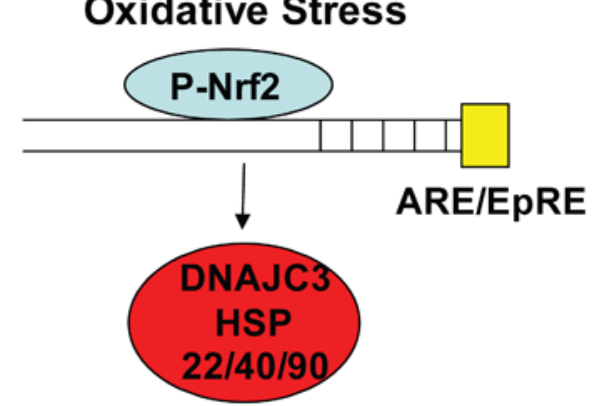

\section{Chaperone and Stress Response proteins}

Fig. (3).

Up-regulated carboxylesterase and DNAJC3 (heat shock proteins) in mitochondria of nontargeted liver of rats whose head was exposed 20 months earlier to $1100 \mathrm{MeV} /$ nucleon titanium ions participate in cell survival functions (NCOA: Nuclear receptor coactivator 1; RXR $\alpha$ : Retinoid receptor $\alpha$; PXR: Pregnane X receptor; Nrf2: NF-E2-related factor 2; ARE/ EpRE: Antioxidant response element/Electrophile response element; DNAJC3: DnaJ homolog subfamily $\mathrm{C}$ member 3 ) 
Table 1

List of proteins found altered in non-targeted liver of rats whose head was exposed to $50 \mathrm{cGy}$ from ${ }^{48} \mathrm{Ti}$ ions (1100 MeV/nucleon)

\begin{tabular}{|c|c|c|}
\hline Protein Name & Accession No. ${ }^{*}$ & Ratio (Non-Targeted /Control) \\
\hline 3-ketoacyl-coA thiolase, mitochondrial & 18426866 & -2.37 \\
\hline Alpha-1-antiproteinase & 112889 & -2.57 \\
\hline Ba1-647 & 33086640 & -2.17 \\
\hline Carbamoyl-phosphate synthetase 1 precursor & 8393186 & -2.57 \\
\hline Carboxylesterase 3 precursor & 140969642 & 3.67 \\
\hline Cathepsin D & 42476045 & -3.7 \\
\hline Choline dehydrogenase & 1154950 & -2.17 \\
\hline Fibrinogen gamma chain & 61098186 & -1.57 \\
\hline Ganionic trypsin-1 precursor & 6981420 & -2.17 \\
\hline Glycerate kinase & 157821525 & -2.57 \\
\hline Hydrolase B, serine esterase & 3807109 & 3.67 \\
\hline Liver annexin-like protein & 7108713 & -2.57 \\
\hline Mitochondrial processing protease & 397699 & -2.57 \\
\hline Mitochondrial trifunctional protein, alpha subunit precursor & 148747393 & -2.47 \\
\hline $\mathrm{N}$-acetylneuraminate pyruvate lyase 2 & 157822207 & -2.17 \\
\hline Precursor polypeptide (AA -18 to 547) & 56899 & 3.67 \\
\hline Preproapolipoprotein A-I & 55747 & -2.37 \\
\hline Protein disulfide-isomerase A3 precursor & 8393322 & -2.57 \\
\hline Protein kinase inhibitor $\mathrm{p} 58$ precursor & 11560030 & 1.57 \\
\hline Pyruvate carboxylase precursor & 31543464 & -1.57 \\
\hline Rieske Fe-S protein precursor & 206681 & -8.71 \\
\hline Serine protease inhibitor $\mathrm{A} 3 \mathrm{~N}$ & 2507388 & -3.07 \\
\hline Stress- 70 protein, mitochondrial & 116242506 & -2.17 \\
\hline Sulfite oxidase & 294639 & 1.57 \\
\hline T-kininogen 1 & 60392582 & -4.87 \\
\hline
\end{tabular}

*

Accession no. is from NCBI protein database (ftp://ftp.ncbi.nih.gov/blast/db/FASTA/nr.gz) 